\title{
Migration and its Impact on Political Scenario: The Case of Karachi
}

\author{
Mehtab S. Karim \\ Vice Chancellor and Executive Director, \\ Centre for Studies in Population \& Health, \\ Malir University of Science and Technology, Karachi \\ mehtabkarim@gmail.com \\ $\&$ \\ Dr. Huma Baqai \\ Associate Dean and Associate Professor of Social Science \\ Institute of Business Administration, Karachi \\ hnbaqai@iba.edu.pk
}

\begin{abstract}
The impact of population growth is felt on every wake of life. The movement of population from one country to another or within a country has its own consequences. Goldstone et al (2012) have thus argued, that the world's population is changing in ways that are historically unprecedented, having its own political consequences such as, the performance of the government due to increasing demand for services and the distribution of political power at intra-state level. Thus, internal migration, which is from high fertility rural zones to urban centers -in developing countries like Pakistan- in search of livelihood and employment, results in concentration of population in slums and squatter settlements on the one hand and a youth bulge in urban areas, further contributing to this phenomenon and unprecedented urbanization. State's inability to address this demographic change effectively results in strains resources and poor governance. In turn, it creates xenophobia, where native populations blame the new migrants for deteriorating civic amenities; and generates various conflicts of critical nature. Pakistan, since its inception as an independent country, has experienced both international and internal migration that resulted in socio-economic crisis, political agitation and violent ethnic conflicts. In this backdrop, this
\end{abstract}


paper takes into account the migration patterns in Pakistan since 1947 and focuses on Karachi for it being the most affected city. It theorizes that the conflict matrix of Karachi is fairly indicative of fault lines and argues that these fault lines will turn into gaping holes if timely actions are not taken.

Key words: Migration, Karachi, Political Scenario

\section{INTRODUCTION}

Demographic movements have played a vital role in Pakistan's creation and its subsequent evolution. The partition of the Indian subcontinent into two independent countries led to the largest migration stream within a year in human history. Over six million Muslims immigrated from India to then West Pakistan while about five million Hindus and Sikhs left for India. Thus, Pakistan gained approximately one million people as reported in the 1951 census of Pakistan. (Selier, \& Karim Eds., 1986). The 1951 census also reported, that then every fifth person was a refugee from India (Jullani, 1962). According to the United Nations 2019 report, Pakistan went from the $12^{\text {th }}$ largest country of the world to the $5^{\text {th }}$ largest in 2019, thus recording the highest growth rate in Asia, only behind Afghanistan.

Among its South Asian neighbors, Pakistan has the highest fertility rate. As per the United Nations estimates, even if the present growth rate declines to $2 \%$ (from current growth rate of $2.4 \%$ ) by 2030, Pakistan will have a population of 269 million people. The 2017 census counted 35.1 percent of population living in urban areas, which translates into 77.4 million as urban residents in $\mathrm{n} 2020$. It's likely that since the 2017 census was conducted on dejure basis, the number of people living in urabn areas could be much higher (Karim, 2017, Oct 17).

According to official statistics, the country has an unemployment rate of $5.7 \%$. However, the actual figures of unemployment and underemployment are estimated to be much higher (Syed, 2020, March 10). These issues are further exacerbated by rampant poverty, an everyday 
reality for 80 million people, low literacy rates, poor healthcare and poor governance. Pakistan's total literacy rate is about 59 percent with less than 47 percent of women being literate (United Nation Human Development Program, 2020), which has implications for the country's human development. Pakistan is ranked on the Human Development Index (HDI) 2019 at $152^{\text {nd }}$ position out of the total 189 countries, which is lower than other South Asian countries.

\section{POLITICAL DEMOGRAPHY OF PAKISTAN}

The demographic and political landscape of Pakistan was highly affected as a result of large scale migration of Muslims from India, as shown in table 1. Thus, the 1951 census of Pakistan counted a population of 33.0 in then West Pakistan, of them about 6.5 million had immigrated from India. The country experienced a demographic phenomenon impacting the political landscape. Post-partition, 85 percent of those who immigrated from India settled in Punjab, largely replacing Hindus and Sikhs who had emigrated to India. On the other hand, although from Sindh less than 100,000 people had emigrated to India, the Province hosted 900,000 million immigrants, which was about $14 \%$ of all immigrants, who mostly originated in central region of India settled in Sindh. Later, a majority of those who had originated in the Eastern region also moved to Sindh. (Selier, \& Karim, eds., 1986). 
Table 1

Number of immigrants from different regions of India who settled in different province of Pakistan

\begin{tabular}{|c|c|c|c|c|}
\hline \multirow{2}{*}{$\begin{array}{l}\text { Migrated from } \\
\text { Regions of India } \\
\end{array}$} & \multicolumn{3}{|c|}{ Number Settled in Provinces of Pakistan } & \multirow[b]{2}{*}{ Pakistan } \\
\hline & Punjab & Sindh & $\begin{array}{l}\text { North West Frontier } \\
\text { Province and } \\
\text { Balochistan }\end{array}$ & \\
\hline East & 121,200 & 38,000 & 24,200 & 183,400 \\
\hline Central & 17,200 & 588,500 & 4,700 & 91,600 \\
\hline North-West & $5,146,700$ & 69,700 & 47,900 & $5,783,100$ \\
\hline West & 5,400 & 151,200 & 1,400 & 158,000 \\
\hline South & 800 & 18,200 & 400 & 19,400 \\
\hline Total Immigrated to & $5,291,300$ & 865,600 & 78,600 & $6,235,500$ \\
\hline $\begin{array}{l}\text { Of all the immigrants } \\
\text { percent settled in: }\end{array}$ & 84.8 & 13.9 & 1.3 & 100.00 \\
\hline
\end{tabular}

Source: 1951 census of Pakistan

In 1951, the population of East Pakistan was then 34 million, which by 1971, had increased to 65 million against 58 million in West Pakistan (the former having 7 million more people than the latter). The demand from East Pakistan for a higher share in the country's resources on the basis of its higher share in the population and denial of this demand, eventually led to the dismemberment of Pakistan, post a bloody civil war in 1971. Interestingly, according to the United Nations Annual Development Report 2019 estimates, due to rapid fertility decline in Bangladesh, it has now 168 million people against 220 million in Pakistan (the latter having an excess of 50 million people).

\section{III.A. SITUATION IN SINDH PROVINCE.}

The population inflow from India largely affected the demography of Punjab and Sindh. However, since the immigrants to Punjab spoke the same language as the native population, they were easily integrated, albeit the immigrants from the Indian Punjab being more educated, dominated 
the civil bureaucracy and military leadership. On the other hand, since the immigrants to Sindh had originated from urban areas chose to settle largely in Karachi (then the nation's capital) and other cities and towns of Sindh. Being more educated than the natives Sindhis, and culturally very different originating from the Indian states of UP, CP, Bihar, Rajasthan and Delhi, they spoke a language which was distinctively different from the language spoken by the native Sindhis. They had no desire to integrate with the local Sindhi population and unlike the integration that happened more naturally in Punjab, never happened in Sindh. Due to huge flow of immigrants, Karachi's population grew from about 300,000 in 1941 to over a million in 1951. For more than two decades, they projected themselves as "Pakistani nationals" and consistently rejected a parochial and regional identity (Verkaaik, 1994). However, they preferred calling themselves Muhajirs. Interestingly, even today their descendants are refereed as Muhajirs and since they prefer not to call themselves Sindhis, they claim their nationality as Muhajirs. After East Pakistan became an independent country in 1972, about half a million Urdu speaking people immigrtated to Pakistan, who were largely settled in Karchi. They along with the other Urdu speaking population, formed a political party of their own known as Muhajir Qaumi Movement (MQM), which wanted constitutional recognition as a fifth nationality of Pakistan. This was a redefinition of political identity for a community, that had earlier shunned a particularistic ethnicity in favor of a broader Muslim identity. The rise of MQM occurred in the midst of an ethnic unrest, especially in Karachi, when in the in 1973 constitution, a provincial quota system was introduced, which divided Sindh into urban and rural residents, giving preference in jobs to those having rural domicile. (Canada: Immigration and Refugee Board of Canada, 1990, March 1). By 1991, MQM had established a virtual monopoly, over the representation of an Urdu speaking community in Urban Sindh. (further discussed in section IV.C)

\section{III.B IMMIGRATION FROM AFGHANISTAN}

The Soviet invasion of Afghanistan in 1980 resulted in the inflow of about 3 million Pushto speaking Afghans to Pakistan. Most of them were first confined to refugee camps established in Balochistan and North West 
Frontier Province (now Khyber Pakhtun Khwa or KPK). However, the confinement was never stringent. A census of Afghans in Pakistan conducted in early 2005 by the Population Census Organization on behalf of Ministry of States \& Frontier Regions in collaboration with UN High Commission for Refugees reported 3.1 million Afghan refugees in Pakistan, however, since many had moved and were living in cities, it is likely that they were not accounted for. Of those who were found, 1.9 million were living in NWFP and 135,734 in Sindh. Fifty eight percent were living outside the camps; 82 percent were Pashtuns; 51 percent of the total were males; among males 20 percent were employed and additional 53 percent were daily wage workers; 82 percent had immigrated during 1981-90 and; 82 percent did not show intention to return back to Afghanistan because of economic; security and personal reasons. Fifteen years later, according to UNHCR reports 1.42 million registered Afghan refugees in Pakistan. United Nation Human Rights Council, 2020, March 17). of these, some 444,726 are living in camps and 975,947 are living in settled areas. Since over years many of them, have also acquired national identity cards, thus are consider themselves as Pakistanis. Writing in the Foreign Policy Magazine, Siddiqui argues, that "the country officially hosts 1.4 million registered Afghan refugees, making it home to the one of the world's largest refugee populations (Ladha \& Karim 2012). By most estimates, around a million more immigrants live there without proper documentation". Although only 5 percent are reported to be living in Sindh, however the number of those living in Karachi alone is much greater. Since most Afghan refugees speak Pushto language, they can easily mix with the immigrants from KPK to Karachi, where they are able to carry small business or work as daily wage workers for which they do not need to have national identity cards. There are no properly recorded number of Afghan refugees available for Karachi, however a report prepared for UNCHR and European Commission by Collective for Social Science Research (2005) estimates "at least several hundred thousand, perhaps as many as half a million, people of Afghan origin currently residing in Karachi”. Perhaps in 15 years later, due to high rate of fertility among Afghan women and constant immigration, perhaps their number would exceed 700,000 today (Bansal, 2013).

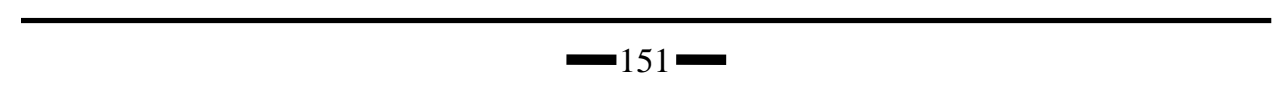


Immigration from Afghanistan have had a tremendous impact on political and social landscape of KPK, where after acquiring national identity cards they have become voters and in some cases won elections and are able to influence the local politics. Since a large number of them has also moved to Karachi in search of livelihood, serving as ordinary laborers, petty businessmen and owners and drivers of mini-buses. Especially in the absence of any public transport system in Karachi, Afghan's have been dominating the private transport sector in the city. The internal migration from KPK of Afghan Pashtuns and Pakistani Pashtuns (from KPK and FATA) has turned Karachi into having one of the largest Pashtun population in the region. At present there are more Pashtuns in Karachi than in Peshawar, Kandahar or Kabul having an impact on the security situation in the country as well as in Karachi (Gul Khattak, S. 2003).

\section{III.C INTERNAL MIGRATION TOWARDS SINDH}

Since the late 1950s, Sindh has been receiving a much larger share of internal migrants as compared to Punjab and KPK, resulting in an increase in Sindh's share in the country's population from 17.9 percent in 1951 to 22.6 percent in 1981. Sindh's share barely increased 23 percent in 1998 census and has remained the same in 2017 census. Although the 1998 census indicated that Sindh received substantially higher number of interprovincial migrants, when compared to Punjab and NWFP (see Table 2) the results were surprising. Similarly, the results of 2017 census indicate, that the share of Sindh in the country's population has not changed which was perhaps due to the undercounting of Sindh's population in general and Karachi in particular, which was widely reported and discussed on the electronic and print media. For this reason the provisional results of the 2017 census have become controversial, and official results have yet not been released. Further analysis of provisional results of the 2017 census data indicates, that due to political considerations, the population of Sindh province in general and of Karachi city in particular, was substantially under-counted to the tune of about 8 million, whereas the population of Punjab and KPK were over-counted (Karim, 2017, Oct 17). Unfortunately, unlike the previous five censuses conducted in Pakistan, the 2017 census did not collect information on migration, therefore, 
patterns of inter-provincial migration during the past ten years remain undocumented in the 2017 census. This is seen by many as a deliberate attempt to use demographic representations as a tool of social, political and economic manipulations. For example, the percentage of seats in the National Assembly allotted to Sindh has remained the same as in 1981 although fertility in Sindh has remained as high as in other provinces and Sindh has been getting a major share of inter-provincial migrants. The constant share of Sindh in the national population also affects allocation of resources under the National Finance Commission (NFC) awards, where population is given 85 percent weightage.

Table 2

Inter- and Intra-Provincial Migration in Pakistan Ten Years Prior to the 1998 Census

\begin{tabular}{|c|c|c|c|c|c|}
\hline & Punjab & Sindh & NWFP/KPK & Balochistan & Total \\
\hline \multicolumn{6}{|c|}{ Migrated within the Province } \\
\hline Number & $1,321,200$ & 319,200 & 182,600 & 56,100 & $1,879,100$ \\
\hline \multicolumn{6}{|c|}{ Migrated from outside the Province } \\
\hline Number & 772,000 & 949,100 & 143,800 & 77,200 & $1,942,100$ \\
\hline \multicolumn{6}{|c|}{$\begin{array}{l}\text { Of all Inter-provincial migrants } \\
\text { who settled in each Province }\end{array}$} \\
\hline Percent & 39.8 & 48.9 & 7.4 & 3.9 & 100.0 \\
\hline \multicolumn{6}{|c|}{ Share in the country's population } \\
\hline Percent & 55.6 & 23.0 & 13.4 & 5.0 & $97.0 *$ \\
\hline
\end{tabular}

* Source: Pakistan Bureau of Statistics.

* Total percentage does not add to $100 \%$ as $3 \%$ of the population lived in federal territories; FATA and Islamabad.

\section{THE CASE OF KARACHI}

Karachi has remained not only the largest metropolis of Pakistan, but is the country's commercial hub, generating about half the country's revenue. The city is also known as "mini Pakistan" where people from all the districts of Pakistan have migrated (Mumtaz, 1987). Among the megacities of the world, Karachi city is considered as overly populated, ethnically diverse, politically volatile and poorly managed (Selier, \& 
Karim, eds., 1986). The city therefore, makes an interesting case for an enquiry in the domains of political demography.

\section{IV.A Population Growth}

Karachi's growth is parallel to none; no other city anywhere else in the world, at any time in human history, has ever experienced such an enormous growth rate. Karachi experienced a population growth rate of $432 \%$; from a city of 450,000 in 1947 , it has turned into a demographic pressure cooker of 22 million inhabitants in recent times (Anwar, 2012).

Historically, post-colonial megacities' premier economic status contributed to an enormous increase in their populations. As shown in Table 3, the population of Karachi grew from about 300,000 in 1941 to over a million in 1951, mainly due to immigration from India. Since then, there has been a constant internal migration to Karachi from other provinces, as well as inflow illegal immigrants from other South Asian countries, resulting in a phenomenal population growth, resulting in over five fold increase in the city population during 1951 and 1981 while during the same period, Pakistan's population recorded 2.5 fold increase. During 1981-1998 Karachi's population almost doubled as reported officially in the 1998 census. However, about 2 million people -who were considered illegal aliens-were not included in the official figures, because the census officials considered them as illegal immigrants from Bangladesh, Burma (Myanmar) and Afghanistan (Karim, 2017, Oct 17). Although during the past inter-censal periods the annual growth arte of Karachi varied between 4 and 10 percent (largely due to internal migration), which were substantially higher then the national average, the 2017 census records an annual growth rate of 2.4 percent in Karachi as in the country, suggesting almost no in-migration to Karachi during the past 19 years. Thus, about 14.9 million inhabitants were counted in Karachi city, where as the estimated population of Karachi was 22 million by an international organization (Cox 2017, April 21). 
Table 3

Population Growth in Karachi: 1941-2017

\begin{tabular}{|c|c|}
\hline Census Year & Total Population (million) \\
\hline 1941 & 0.3 \\
\hline 1951 & 1.1 \\
\hline 1961 & 1.9 \\
\hline 1972 & 3.5 \\
\hline 1981 & 5.2 \\
\hline 1998 & $9.2\left(11.2^{*}\right)$ \\
\hline 2017 & $14.9\left(22.1^{* *}\right)$ \\
\hline
\end{tabular}

* includes 2 million inhabitants who were considered aliens, therefore were not included in the official figures.

**Source:www.newgeography.com/content/005593-the-largest-citiesdemographia-world-urban-areas-2017

\section{IV.B Changing Political Landscape}

After declaring martial law in 1958, General Ayub Khan a year later moved the nation's capital from Karachi, for an interim period to Rawalpindi and later established a new capital, Islamabad. Since then, the tussle to hold the reigns of Karachi has been on, with ethnic tensions dominating the wide range of conflicts. Consequently, in the 1964 elections, out of 16 administrative Divisions in the then West Pakistan, Karachi was the only Division where an overwhelming electorate voted against President Ayub Khan's indirect election through the Basic Democracy system. For doing so Karachiites were penalized with the first ethnic riots in Karachi, between Muhajirs and Pashtuns, who were encouraged to settle in Karachi by then Commissioner, who like General Ayub Khan, was from the North West Frontier Province (presently Khyber Pakhtunkhwa).

The repercussion of cultural and linguistic polarization in Sindh was again reflected in the first general elections held in 1970, when electorate of Karachi and Hyderabad --the two largest cities of Sindh where Muhajirs are in a majority-- supported mainly the two religious political parties and 
overwhelmingly voted against Peoples Party of Mr. Z.A. Bhutto. Once in power, Bhutto tried to isolate the Muhajirs from the mainstream, by declaring that since the residents of urban areas of Sindh (a majority of them were Muhajirs) were over-represented in civil bureaucracy as well as in the nationalized industries and banks, therefore in all the new appointments, preference should be given to those from rural areas of the province. Thus, for the first time and only in Sindh province, an urbanrural quota system was introduced in the 1973 constitution initially for 10 years, which remains in force till present day.

\section{IV.C Emergence of MQM}

After East Pakistan became an independent country of Bangladesh in 1972, a half million people--most of whom or their parents had immigrated from the Indian State of Bihar and UP in 1947--opted for Pakistan. Since most had relatives living in Karachi and spoke Urdu language, they preferred settling in Karachi. Besides, since most belonged to educated families, therefore, their children were admitted at Karachi University or medical and engineering colleges in Karachi. They joined already disenchanted Urdu speaking students who had developed a sense of deprivation due to the new quota policy in Sindh, which was keeping urban residents out of the government jobs and other public sector organizations. Thus in 1976, the Urdu speaking students attending colleges and universities in Karachi and Hyderabad, organized themselves into a group, calling themselves All Pakistan Muhajir Students Organization. The only common factor among them was that their parents had immigrated from either from India to Karachi and other towns of Sindh or via Bangladesh. Therefore, they were labeled as Muhajirs (refugees). When these students graduated with degrees and no prospects for proper jobs, they formed a political party, Muhajir Qaumi Movement (MQM) to fight for the rights of Muhajirs in Sindh. This new nationalist group in Sindh emerged in response to relative economic deprivation, which was common in the Muhajir community in the 1970s and the following decade (Ahmar, 1996), (News Pakistan Admin, 2013, August 6), (Haq, 1995), (Wassem, M. 2004). 
In the 1986 local body's election, MQM showed its muscle and its candidate was elected as the Mayor of Karachi. When democracy was restored after the death of General Ziaul Haq, in the 1989 elections MQM won about 85 percent of the national and provincial assembly seats from Karachi. Thus, in both the Federal and the Provincial governments, MQM was a coalition partner with the Peoples Party of Benazir Bhutto. After her dismissal, in the next election two years later, MQM again won most of the seats and this time Muslim League led by Nawaz Sharif formed the government with the support of MQM.

The fascist dimensions of the MQM under the leadership of its founder Altaf Hussain was now an open secret. This led to a crackdown by the military against MQM leadership in 1992, resulting in the top leadership of MQM going into hiding, while Altaf Husain fled to London, and sought political asylum. After the removal of Nawaz Sharif in 1998, by General Pervez Musharaf, who belonged to an Urdu speaking family from Karachi, all charges against MQM leaders were dropped and in the 2002 elections, the party again won most of the seats from Karachi and joined the coalition governments in Sindh as well as at the Federal level.

MQM remained a coalition partner of Peoples Party's government which won a majority of seats in Sindh in the 2008 elections. However, after remaining in power for 10 years, when Muslim League $(\mathrm{N})$ in the National Assembly and Peoples Party in the Sindh Assembly won enough seats in the 2013 elections, the two parties formed the governments on their own strengths. Thus, MQM was not a coalition partner at national or provincial level during 2013-18. In the meanwhile, Altaf Husain who has been living in London in self-exile, in 2017 issued several statements which were considered against the ideology of Pakistan, therefore, the local MQM leadership disowned him. Since then, MQM has been in a disarray, and has been spilt into three group.

The constant waves of migration to Karachi from other provinces have changed the ethnic complexion of the city. A large number of these migrants originate from NWFP and are Pashtun speaking. This increase is substantial from 5 percent in 1981 to 11 percent in 1998, whereas the share 
of Urdu-speaking population in Karachi declined from 54 percent to 48 percent during the same period. Distribution of Karachi's population by mother tongue based on the 2017 has not yet been released. However, post 9/11, conflicts and surgical strikes in Afghanistan and in FATA and internal conflicts in KPK, has most likely accelerated Pashtun migration from these areas. Thus, the share of Pashtun population in Karachi is likely to have increased further, resulting in the relative decline of Urduspeaking (Muhajir) population.

MQM dominated the politics of Karachi for three decades, but the 2018 elections had a different story to tell. MQM lost a majority of Karachi's seats in both the National and Sindh Assembly. From an average of winning 18 out of 20 seats from Karachi to the National Assembly in earlier elections since 1989, in the 2018 election, MQM could win only four seats. On the other hand, Imran Khan's Pakistan Tehrike Insaaf (PTI), won 14 seats, showing an overwhelming number of Muhajirs switching their loyalty to PTI. For this change, many Muhajirs have been rewarded and have been appointed in the Federal cabinet, which is much higher than their share in the national population. Besides, MQM is also a collation partner in the Federal Government. On the other hand, in Sindh, both PTI and MQM are in opposition against PPP. Besides, the mayor of Karachi is from MQM and there is constant tussle between him and the provincial government. Thus, Karachi suffers due the breakdown of civic infrastructure.

\section{C Violence and Conflict in Karachi}

About 40 percent of Karachi's population lives in katchi abadis (squatter settlements), which are poor neighborhoods, devoid of most basic civic amenities. The rich-poor divide marks every group's interest that exists in Karachi, be it mainstream liberal, centrist ethnic or religious parties. Karachi has been in the grip of turmoil and violence since the mid-1980s. After the ethnic riots of 1964, Karachi experienced language riots in 1973 when newly elected provincial assembly of Sindh declared Sindhi as the official language of Sindh province. Muhajirs considered it an insult to their mother tongue Urdu, also the national language of Pakistan and thus 
they were on the sreet to protest against this move. This led to sporadic violence and ethnic conflict, which had not surfaced in Karachi for a decade. But this time, it was between the two major ethnic groups in Sindh, Muhajirs and Sindhis, ho have lived peacefully together since 1947. The tension also led to migration of many Urdu speaking families from other town of Sindh to Karachi. However, soon with interference from Mr. Bhutto things were calmed down. But Karachiites took the revenge and overwhelmingly supported the opposition alliance PNA which was instrumental in the overthrow of Mr. Bhutto's elected government resulting in the imposition of Marshal Law of General Zia ul Haq in 1977. General Zia ul Haq was mainly responsible for encouraging Afghan refugees to move from camps in KPK and look for livelihood in cities of Pakistan and allowed them to operate small business including local transport. They mostly moved to Karachi and settled in its suburb Sohrab Goth, which later became notorious for smuggling of arms and drugs from Afghanistan. Many rich Afghan refugees were also allowed by the Government to operate fleets of mini-buses in Karachi using Afghan refugees as drivers, many of whom drove on the streets of Karachi without any drivers' license.

Consequently, an Urdu speaking college student -Bushra Zaidi- while crossing the street was crushed to death by a presumably Pashtun minibus driver, who disappeared from the scene leaving the vehicle behind, which was put on fire by a mob which had assembled there. This led to an ethnic tension between Pushtuns and Muhajirs. A few days later, Aligarh colony largely inhabited by Muhajirs, was attacked by Pashtuns with automatic guns, killing several people. This added fuel to fire and violence erupted between the two communities. Karachi's economic activities were severely hampered by cyclic violent disruptions caused by ethnic groups, terror outfits and criminal mafias for years. According to police records, during the next decade, over 9,000 people were killed in Karachi, about 29,000 four wheelers and over 100,000 two wheelers were stolen along with 100 cases of bank robberies.

However, the violence matrix of Karachi is not about law and order. The law and order situation is apparently a by-product of the demographic 
convulsions the city has been experiencing since the early 1960 s, too many people moving to the city from all over the country, while most of the city's population has been deprived of the basic civic amenities, a phenomena identified in the mid-1980s (Karim, 1987, February 27), which led to wide spared riots (Hussain, 1987). Since then, violence has continued in Karachi which is considered as one of the most violent cities of comparable size in South Asia as reported by key international newspapers and magazines. According to one estimate, there were a significant number of lethal weapons, many of them unlicensed and illegally held in Karachi, which was one of the major factors for murders and injuries (Chotani, Razzak, \& Luby, 2002). In 2001, the murder rate in Karachi was 4.04 per 100,000 population and between 1994 and 2004, there were 8,816 casualties reported through incidents of violence including murders, torture by non-state actors, kidnappings for ransom, vigilante reprisals, bombings and suicide attacks. Lately, low intensity violence is carried on without any gap (Ali Budhani, et al. 2010). The life in Karachi gets a jolt only when killing, crime and violence cross a certain limit.

The operation by Pakistan Army against Taliban in the valley of Swat in 2007 and 2009 resulted in internal displacements of many people. Thousands left their homes and Karachi was the obvious choice for them to settle in which was already home to some millions of Pashtuns. This trend gained momentum in 2009, when the military operation reached South Waziristan, Mohmand Agency, Bajaur and Dir. This resulted in unchecked migration to Karachi from KPK, FATA as well as Afghan refugees.

This culminated in the coming of Tehreek-e-Taliban Pakistan (TTP) to Karachi. They were also the new entrant to the club of Karachi conflict stake players (Baqai \& Hassan, 2017). TTP identified Karachi perfectly suitable for rest and recuperation as well as started using the city's resources to fund its pursuits. This continued unabated till they enveloped the city, using the shield of Mohajir-Pushtun conflict to their advantage to a point where they controlled parts of Karachi and were held responsible for most of the terrorist attacks in the city. They contend that in the 
beginning, TTP wanted to blend in with the local Pashtun population, so they cut their trademark long hair, shaved their beards and worked as petty labourers. They quote the Economist of August 5, 2008, where a spokesman for Mr. Mehsud threatened to bring jihad to Karachi, Pakistan's biggest city and home to many poor Pashtuns. Gradually understanding the politico-ethnic-religious nexus of violence in Karachi, TTP started carrying out it war in the city, which provided them with the perfect cover.

During 2010-11, TTP employed a covert strategy and worked under the cover of political and religious parties to escape the attention of law enforcement agencies. In areas under their control, TTP started levying a tax on residents and businesses and dug deep into the areas populated by Pashtuns, creating virtual "no-go-areas", terrorizing the local population. It appears that after the operation clean-up by the security agencies in Karachi, the Talibanization of Karachi has perhaps died down. However, despite these successes, religious militancy in Karachi is deeply entrenched and has many manifestations. This politico-religious configuration gives militants the operational space that cannot be addressed by operations by security agencies alone. The security agencies have done the ground work which has pushed TTP to a position of weakness, but given the sympathy they enjoy among a segment of Pashtuns living in squatter settlements of Karachi, especially those who are young and mostly belonging to the have-nots category, on the one hand, and having a deep rooted fundamental religious belief on the other, the non-state actor can re-organize any time in the future.

\section{CONCLUSIONS}

At a time when Pakistan is facing major political, economic and social change, demographic phenomena which has been largely ignored, needs due consideration and needs to be put on the centre stage. By 2035, about 50 percent of Pakistan's population will be living in urban areas, with about 40 percent of urban areas population consisting of youth in the agegroup 15-29. This makes Pakistan one of the youngest countries in the world. The youth bulge of Pakistan can only be turned into an asset, if the 
demographic changes, which include internal migration amongst other factors is incorporated into policy foresights. The political landscape of Pakistan in general and of Karachi in particular cannot be understood in totality, unless the demographic configurations are taken into account. The manipulation of census by not showcasing the waves of demographic movements will blind sight the policymakers into making blunders that will be hard to correct. The fault lines exist; the conflict matrix of Karachi is fairly indicative of it. These fault lines will turn into gaping holes if timely actions are not taken. It is not about Karachi only; it is about Pakistan. 


\section{References}

Ahmar, M. (1996). Ethnicity and state power in Pakistan: The Karachi crisis. Asian Survey, 36(10), 1031-1048.

Ali Budhani, A., Gazdar, H., Kaker, S. A., \& Bux Mallah, H. (2010). The Open City: Social Networks and Violence in Karachi. Working Paper No. 70.

Anwar, F. (2012). Karachi City Climate Change-Adaptation Strategy A Roadmap. Journal of Research in Architecture and Planning. 11(1).

Bansal, A. (2013). Ongoing Talibanization of Karachi. Asia Pacific Bulletin. No 209 Washington: East-West Center. http://www.eastwestcenter.org/sites/default/files/private/apb_209.pdf.

Baqai, H., \& Hassan, M. (2017). Paradigm Shift in Karachi's Conflict Matrix: A Case Study. Pakistan Perspectives, 22(2).

Canada: Immigration and Refugee Board of Canada. (1990, March 1). Pakistan: Quota system for Mohajirs in education or employment?. https://www.refworld.org/docid/3ae6ab4990.html.

Chotani, H. A., Razzak, J. A., \& Luby, S. P. (2002). Patterns of Violence in Karachi, Pakistan. Injury Prevention, 8(1), 57-59.

Cox, W. (2017, April 21). The 37 Megacities and Largest Cities: Demographia World Urban Areas: 2017. New Geography. https://www.newgeography.com/content/005593-the-largest-citiesdemographia-world-urban-areas-2017.

Gul Khattak, S. (2003). In/Security: Afghan Refugees and Politics in Pakistan, Islamabad. Sustainable Development Policy Institute, Working paper series.

Haq, F. (1995). Rise of the MQM in Pakistan: Politics of Ethnic Mobilization. Asian Survey, 35(11), 990-1004. 
Hussain, A. (1987). Karachi Riots of December 1986: Crisis of State and Civil Society in Pakistan. Economic and Political Weekly, 450-451.

Jullani, M. S. (1962). The Resettlement Patterns of Displaced Persons in Pakistan. (Doctoral dissertation, University of Chicago, Department of Sociology).

Karim, M. S. (1987, February 27). Karachi’s Demographic Dilemma. Dawn Magazine.

Karim, M. S. (2017, Oct 17). Missing People In Census. Dawn News. https://www.dawn.com/news/1364371.

Ladha, H. \& Karim, S. M. (2012). Reproductive Behaviour of Afghan Refugee Women Living in Karachi. Journal of Population and Social Studies, 21(2).

Mumtaz, K. (1987). Nasra M. Shah (eel.). Pakistani Women: A Socioeconomic Demographic Profile. Islamabad: Pakistan Institute of Development Economics/Honolulu: East-West Center. 1986 The Pakistan Development Review, 26(1), 121-123.

News Pakistan Admin. (2013, August 6). 25-Year History of MQM's Politics, its Friends and Foes. Lahore News: NewsPakistan.pk. http://lahore.newspakistan.pk/2013/08/06/25-year-history-of-mqmspolitics-its-friends-and-foes/.

Selier, F. \& Karim, M. S. (eds.). (1986). Migration in Pakistan: Theories and Facts. Lahore: Vanguard Books.

Siddiqui, Z. (2019, May 9). For Afghan Refugees, Pakistan Is a Nightmare but Also Home Foreign Policy. https://foreignpolicy.com/2019/05/09/for-afghan-refugees-pakistan-isa-nightmare-but-also-home/.

Syed, J. (2020, March 10). Population and Human Development. The Express Tribune. https://tribune.com.pk/story/2172658/6-populationhuman-development 
United Nation Human Development Program, (2020). The Next Frontier: Human Development and the Anthropocene. Human Development Report. http://hdr.undp.org/sites/all/themes/hdr_theme/countrynotes/PAK.pdf.

United Nation Human Rights Council. (2020, March 17). Operational Portal Refuges Situation: Registered Afghan Refugees in Pakistan by location. https://data2.unhcr.org/en/country/pak.

Verkaaik, O. (1994). A people of migrants: ethnicity, state, and religion in Karachi. (Vol. 15). VU University Press.

Wassem, M. (2004). The MQM of Pakistan: Between Political Party and Ethnic Movement. In Political Parties in South Asia. Edited by Subrata K. Mitra, Mike Enskat and Clemens Spiess. Heidelberg: Praeger. 